\title{
A Filosofia no fogo cruzado de direita e esquerda
}

\author{
Philosophy in the right versus left crossfire \\ Julio Cabrera \\ http://orcid.org/0000-0003-2572-3152 - E-mail: kabra7@gmail.com
}

Florianópolis, junho 2020, ano do vírus.

\begin{abstract}
RESUMO
Neste trabalho, tento mostrar que o fato de que o atual projeto institucional da filosofia seja defendido por intelectuais de esquerda é uma contingência. $O$ dualismo: esquerda /direita não coincide com o dualismo filosofia autoral/filosofia institucional. Tento acenar para uma ontologia do dualismo esquerda/direita com o intuito de mostrar como essa dicotomia está norteada pela carga emocional dos conteúdos, mais do que pelos conteúdos mesmos. Nesse viés, pode mostrar-se que esse conflito não tem nenhuma solução positiva porque os próprios componentes do conflito precisam dele e o alimentam constantemente. Se estivermos interessados em filosofia autoral, teríamos que tentar liberar a filosofia do conflito interminável entre esquerda e direita, sendo capazes de reconhecer boa filosofia mesmo no campo político que rejeitamos. Entretanto, o artigo termina com uma sensação de desesperança de que tal projeto pluralista seja sequer possível num momento de polarizações acirradas como o presente.
\end{abstract}

Palavras-chave: Esquerda. Direita. Filosofia autoral. Filosofia institucional. Engajamento. Ontologia.

\section{ABSTRACT}

In this paper, I try to show that it is a contingency that the current project of institutional philosophy has been defended by leftist intellectuals. The left/right dualism does not coincide 
with the dualism of authorial philosophy/institutional philosophy. I try to point to the ontology of left/right dualism, to show how this dichotomy is guided by the emotional load of the contents, more than by these contents themselves. This conflict has no solution because the opponents need it and are constantly feeding it. If we are interested in authorial philosophy, we would have to try to free philosophy from this endless left/right conflict, being able to recognize good philosophy even in the political field that we reject. However, the article ends with a feeling of hopelessness that such a pluralist project is possible at a time of intense polarizations like the present one.

Keywords: Left. Right. Authoral philosophy. Institutional philosophy. Engagement. Ontology.

\section{Direita e Esquerda: primeiras aproximações}

Já faz alguns anos que venho me perguntando o que significa ser de direita ou ser de esquerda. Propositalmente sublinho a palavra "ser", para afastar a ideia de pretender apenas me movimentar num plano político - no qual a resposta poderia ser bastante simples - quando meu propósito é primordialmente ontológico. Interessa-me elucidar dois modos diversos e antagônicos de "ser no mundo", ser no mundo de esquerda, ser no mundo de direita. No plano político superficial, seria possível resumir rapidamente algumas características, já bastante conhecidas, que podem conduzir para esse plano ontológico que gostaria de atingir, num segundo momento desta reflexão.

Quem é "de esquerda" tende a ver o mundo como um movimento histórico e cultural visando um futuro aberto, muitas vezes promissor e às vezes utópico, que aceita os humanos como agentes capazes, apesar de suas limitações, de levar adiante projetos de melhoramento da vida humana no planeta. Quem é de esquerda pensa que há muito por fazer, pois as sociedades humanas são desiguais e injustas, e os oprimidos pelos mais poderosos - os antigos escravos, os atuais assalariados - devem ser liberados, seja por meios pacíficos, seja pela violência. Para isso, acredita-se num Estado forte capaz de se encarregar da distribuição justa e equitativa de benefícios, bloqueando privilégios. Estas ações não estão concentradas dentro das fronteiras de nações, mas visam à humanidade como um todo. Não se pensa que as coisas estejam dadas pela natureza de maneira estática, mas que elas podem ser mudadas radicalmente pela ação humana. A esquerda não descarta o elemento religioso da vida humana, mas Ihe dá um sentido combativo e não meramente de culto a uma transcendência atingível só depois da morte. No que se refere à questão da linguagem, esta é vista mais em suas funções performáticas e transformadoras. Na questão ecológica, a esquerda tende a políticas de preservação da natureza e das espécies animais, contra a sua pura utilização mercantil, oportunizando formas de vida mais respeitosas da natureza não exclusivamente baseadas no lucro (e nesta trilha eles voltam a certas visões romantizadas da vida humana, como as mostradas pelos povos indígenas).

Neste mesmo nível superficial de análise, o que significa "direita"? Quem é de direita não pensa que tudo pode ser criado pela cultura; há uma realidade que tem algo a nos dizer e devemos escutá-la. A vida humana não está apenas tendida para o futuro, mas apoia-se essencialmente em tradições e formas de vida do passado que foram sedimentando e constituindo guias para a nossa vida atual. É claro que os seres humanos são livres e artífices de seus destinos, mas o melhoramento da vida humana não pode ser feito a través de uma revolução total 
das formas de vida existentes, o que pode gerar mais vítimas das que se tentava salvar. O Estado não pode se erigir numa força descomunal capaz de gerenciar as vidas humanas de maneira vertical, mas apenas administrar o que as pessoas conseguem fazer dentro das sociedades civis. Em lugar de visar uma transformação internacional da vida humana, deve-se começar por pequenas ações sociais dentro das comunidades imediatas e dentro do escopo da própria nação, respondendo a sentimentos patrióticos naturais. O ser humano não é tão confiável como para encarregá-lo de gigantescas tarefas de transformação, não está dotado de uma generosidade natural que lhe torne capaz de deixar de lado seus anseios de liberdade e propriedade. A condição dos trabalhadores modernos é melhor que a dos escravos antigos, os progressos são lentos e não podem ser apressados. O fator religioso indica para um lugar sagrado que não pode ser manchado por ações imediatas ou impregnado de ideais seculares. A linguagem mantém fortemente suas funções denotativas de uma realidade que não muda ao nosso bel prazer, e a natureza foi dada aos humanos para a sua realização na Terra, não havendo nada de errado no uso do não humano em benefício do humano. O processo civilizador se impôs irreversivelmente sobre formas culturais primitivas como as indígenas.

É claro que alguém firmemente situado na direita no que concerne ao poder do Estado poderia ter uma sensibilidade ambiental de esquerda, e alguém da esquerda poderia ter receios a respeito da "teologia da libertação" e reconhecer a religião como um lugar sagrado e transcendente. Estes entrecruzamentos acontecem. Mesmo assim, creio que - como ocorre em outros âmbitos - diante do inimigo externo comum os partidários de direita ou de esquerda se encontram com seus aliados ultrapassando rapidamente as suas diferenças internas. Alguém da direita pode manter atitudes indecisas a respeito de religião ou no modo de tratar os animais, mas diante do risco de implantar-se no Brasil um regime à la Fidel Castro, eu penso que todos os simpatizantes da direita se reuniriam de imediato num mesmo grupo, deixando de lado suas outras desavenças. As noções são definidas mais pelo que rejeitam que pelo que abrangem.

Já nestas distinções empíricas de cunho político podemos ver que direita e esquerda são basicamente duas maneiras de organizar a vida humana, o que significa também a morte humana e a finitude. Para levar estas distinções a um plano ontológico haveria que indagar-se pelo específico modo de "ser no mundo" daqueles que organizam as suas vidas de acordo com umas ou outras dessas características. Ser, temporalidade, espaços disponíveis, linguagem, finitude, morte, divindade, são lugares de discordância ontológica no modo mesmo em que humanos se inserem no mundo em duas direções muito diferentes e sempre em conflito. Mas por que em conflito? Vejamos em detalhe este aspecto antes de empreender a análise ontológica na seção 4 deste artigo.

\section{Caminhos do "engajamento": uma direita sartreana?}

Que significa este "versus" do conflito: “Esquerda versus Direita"? Qual é a sua força de exclusão e, consequentemente, as suas possibilidades de articulação mútua? Para tentar entender se estas duas atitudes diante do mundo e do humano poderiam, apesar de tudo, conviver em algum tipo de sociedade sem se destruir mutuamente, gerenciando, de alguma forma, as suas diferenças, começo me perguntando como se escolhe ser de direita ou de esquerda, por que preferir uma organização da vida de direita e não uma de esquerda ou vice-versa? Em que nível se toma essa decisão? E trata-se realmente de uma escolha? Pois poderia ser incorreto usar esse termo se por "escolha" se entende algo plenamente racional e consciente. Poderia tratar-se, em muitos casos, apenas de um encaminhar-se para, algo que a palavra "decisão" talvez capte 
melhor. A decisão poderia parecer-se com a movida no tabuleiro de um jogo mais do que com uma escolha existencial profunda.

Nessa trilha, pareceria que esta decisão é diferente em pessoas com menos elementos culturais e ferramentas intelectuais e nas pessoas mais intelectualizadas (entre as quais estão os filósofos, dos que tratarei especificamente na seção 3). Podemos ver que as massas - de qualquer classe social ${ }^{1}$ - que votam numa eleição não têm ideias muito claras acerca do que significam conceitos como socialismo, comunismo, fascismo, capitalismo, nem conhecem a complexa - e frequentemente sombria - história destes conceitos. A maioria vota ou de maneira indiferente e automática ou levada pela propaganda, por simpatias superficiais, por promessas vagas, por interesses imediatos ou por rejeição de alternativas que acham piores. Pessoas que pouco sabem sobre política ou história, que vivem suas vidas de maneira irrefletida, grande parte delas submersas em trabalhos exaustivos para conseguir sobreviver, são de repente obrigadas a "optar", às vezes no mesmo dia da eleição, sem ter ideia clara do que se trata e de quais serão as consequências da sua decisão².

Aqui podemos nos perguntar se esta decisão é sensivelmente diferente nas pessoas que pareceriam mais esclarecidas, nos intelectuais, artistas, políticos, professores, empresários, dirigentes, que leem e escrevem livros, que conhecem história e sabem o que significa escolher entre um ou outro lado. Neste caso, estaríamos mais perto de uma autêntica "escolha", livre, racional e esclarecida? Neste ponto, as respostas começam a ser surpreendentes. Numa primeira fenomenologia de atitudes é possível ver, sem dúvida, que as pessoas mais instruídas e melhor informadas sustentam argumentos em favor de uma postura ou de outra: tópicos como a conveniência da socialização de bens como caminho para a igualdade, ou as vantagens de uma visão não capitalista da natureza, ou a defesa de um Estado mínimo para salvaguarda da liberdade, etc., tudo isto pode ser argumentado de ambos os lados e dar pé para discussões filosóficas bem fundamentadas.

Mas o que chama poderosamente a atenção é que, apesar de que as opções políticas são aqui muito mais refletidas e melhor apoiadas em conhecimentos que a decisão das massas, aqueles que optam pela esquerda ou pela direita habitualmente o fazem de uma maneira que acentua fortemente - mais inclusive do que as massas - aquela oposição absoluta antes mencionada, rejeitando de plano tudo o que venha da outra facção como a encarnação mesma de um mal absoluto, como uma força maligna com a qual nem sequer vale a pena dialogar, mas apenas se defender dela e tentar eliminá-la. É difícil ver pessoas intelectualizadas aceitando alguns valores da esquerda e alguns da direita de maneira ponderada e seletiva; em geral, as posturas são aceitas ou rejeitadas em block.

Assim, a atitude dos mais intelectualizados e melhor informados de qualquer facção não parece menos emocional que a decisão das massas ${ }^{3}$, como se todo seu enorme acervo de cultura histórica e política não fosse suficiente para represar uma adesão fortemente carregada de afeto e de agressividade para a outra parte. Pelo contrário, pareceria que as emoções recebem novos estímulos por parte do acervo cultural, como se o maior grau de ilustração aumentasse ainda mais o grau de ferocidade e agressividade da oposição entre ambas.

\footnotetext{
1 Utilizo aqui a noção orteguiana de "massa": "A divisão da sociedade em massas e minorias excelentes não é, portanto, uma divisão em classes sociais, mas em classes de homens, e não pode coincidir com a hierarquização em classes superiores e inferiores.(...) a rigor, dentro de cada classe social há massa e minoria autêntica" (ORTEGA Y GASSET, 2016, p. 82).

2 Estou falando, claro, de uma média, num nível de generalidade que não pode excluir, evidentemente, casos concretos de pessoas de pouco nível cultural, agudas em suas escolhas políticas, e de pessoas obtusas de classes intelectualizadas. Se ficássemos no plano dos casos particulares, nunca poderíamos fazer uma análise filosófica de qualquer coisa.

${ }^{3}$ De fato, quando eles adotam essa atitude os "intelectuais esclarecidos" passam a fazer parte da "massa" no sentido de Ortega, com independência da sua classe social.
} 
Jean-Paul Sartre tinha precisamente essa noção do que deveria ser um "engajamento" político: o compromisso com a esquerda devia ser total e absoluto, racional e emocional ${ }^{4}$; se tratava de destruir o adversário - o explorador, o burguês - sem escutá-lo, posto que ele, sistematicamente, ia defender seus interesses e jamais se abriria para um diálogo que debilitasse seu poder. Os dados estavam jogados, não havia mais nada para discutir ou dialogar. Precisamente, em sua famosa ruptura com Albert Camus, Sartre e outros acusaram Camus de "incapacidade de engajamento", porque ele não conseguia abraçar de maneira absoluta um lado contra o outro; ele sentia que, chegado certo momento, tinha que criticar ambos. Camus teria declarado, num artigo, que "se a verdade me parecesse estar à direita, eu estaria lá" (ARONSO, 2007, p. 224) 5 . Pareceria que o fator emocional desempenha um papel importante nesta noção forte de "engajamento", na medida em que os argumentos são discricionais e seletivos, enquanto as emoções tendem a aceitar e rejeitar de maneira global. Há um tom afetivo típico do engajamento, que poderíamos ligar com a indignação, a raiva e o ódio.

Mas o curioso é que também os militantes da direita - pelo menos no sentido de nossa caracterização inicial desses termos - adotam a noção sartreana de engajamento só que em sentido contrário: se trata de acabar com o comunismo, não de entabular nenhum tipo de "diálogo" com ele; pois, como dialogar com aqueles que querem nos destruir? Mas, paradoxalmente, com isso a direita adota uma noção formulada por um pensador de extrema esquerda; "engajamento" é um conceito nômade que pode ser capitalizado por qualquer lado. Trata-se de abraçar de maneira absoluta e irrenunciável um dos lados da disputa tentando eliminar a outra, já que nenhum diálogo ou convívio é possível com ela. Enquanto as massas apenas escolhem emocionalmente de uma maneira mais direta, os esclarecidos "engajados" à la Sartre - de direita ou de esquerda - dirigem suas emoções contra os adversários com o explícito intuito de derrotá-los e, se possível, eliminá-los do planeta. (Também aqui trabalho com uma média não distributiva em indivíduos; não nego, por exemplo, a existência de simpatizantes da direita que não adotem a noção sartreana de engajamento).

Neste nível de decisão, há, pois, entre direita e esquerda um tipo muito peculiar de rejeição ou de exclusão, que me interessaria entender aqui. Pois, em geral, recusamos algo - uma ideia, uma proposta, uma tese - depois de ter tomado conhecimento dela, de ter mergulhado cuidadosamente em seu conteúdo, de ter lido os autores relevantes, etc., elementos que nos permitem tomar uma posição e depois rejeitar. Mas aqui estamos diante de uma curiosa forma de rejeição de ideias que, muitas vezes, não requer esse conhecimento prévio nem precisa de muita leitura nem de informação apurada ou argumentação cautelosa; trata-se de uma recusa que vive de si mesma, que se autoalimenta e avoluma sem precisar de subsídios, que pode rejeitar sem conhecer.

É claro que sempre se pode alegar que já se conheceu o suficiente no passado sobre a postura recusada, de tal forma que o conhecimento acumulado pode ser suficiente para uma condenação sumária agora. Mas isto significa que as rejeições do passado podem renovar-se indefinidamente sem precisar de reciclagem, sem tomar conhecimento do que foi feito ou escrito ulteriormente. Assim, a pergunta se renova: como justificar filosoficamente uma rejeição que não precisa mais passar pelo crivo da razão e dos argumentos? Como pode ser legitimada uma forma de interação que é a negação radical de toda e qualquer interação?

\footnotetext{
${ }^{4} \mathrm{Na}$ filosofia de Sartre os fatores emocional e racional não estão nitidamente separados e mantêm relações complexas, como se pode ler em seu ensaio juvenil Esboço de uma teoria das emoções e em sua obra magna O Ser e o Nada.

${ }^{5}$ Esta mesma atitude foi assumida no cinema pelo cineasta Greco-francês Konstantin Costa-Gavras, ao fazer sucessivamente $Z$ (1969), um filme contra o militarismo de corte fascista e, logo a seguir, A Confissão (1970), um filme contra o Stalinismo; na época, ele foi acusado de ter anulado a sua primeira crítica com a segunda.
} 
Resumamos a situação. A pergunta de se esquerda e direita poderiam conviver numa mesma sociedade humana - não digamos harmonicamente, mas na forma de um conflito gerenciável - tende a ganhar uma resposta negativa à luz da evidência de que, com independência do nível cultural, as decisões por um lado ou por outro parecem marcadamente emocionais, seja de maneira mais direta, seja de uma maneira mediada, e até estimulada, pelo acervo cultural disponível. Em todo caso, parece que, no momento da decisão, o aspecto emocional é mais forte que o estritamente racional, o que tende a minimizar as chances de constituir uma genuína "escolha", se por tal entendemos uma operação racional e consciente.

Sendo o racional e argumentativo o âmbito natural da filosofia, se poderia pensar que os filósofos se comportariam a respeito da questão "direita versus esquerda" de uma maneira mais ponderada e reflexiva. Tentemos ver agora se isso é realmente assim.

\section{O caso da Filosofia}

\section{Como ser um filósofo francês no Brasil}

Pelo que tenho pesquisado e vivido durante muitos anos de atividades filosóficas nas universidades brasileiras, parece-me que esta situação de polarização extrema entre direita e esquerda, encenada mais pelas emoções do que pela disposição a uma discussão racional, se da também, paradoxalmente, no plano intelectual, e especificamente no âmbito da filosofia. Há, evidentemente, um conteúdo conceptual e argumentativo na oposição, mas ele está como sobrecarregado de um afeto que torna as posturas inconciliáveis, rejeitáveis sem cuidadoso conhecimento prévio. Ambas as tendências veem a outra como totalitária, intolerante e perigosa para a liberdade e para a vida. A direita apresenta a intelectualidade da esquerda como um perigoso dogmatismo, mas quando a esquerda toma conta dos rumos da filosofia apresenta a postura contrária como antidemocrática e totalitária. Assim, quando se focam as atividades filosóficas, de imediato a mesma polarização fica estabelecida, com cada parte assumindo o lugar do bem em contra de um mal absoluto representado pela outra.

Vou ilustrar esta situação da filosofia no fogo cruzado de direita e esquerda com dois exemplos, nesta e nas próximas subseções.

Em 2012, um grupo de professores da USP publicou em Paris um número especial, editado pelo Collège International de Philosophie, sobre filosofia no Brasil, chamado Comment peut-on être philosophe...au Brésil? Essa publicação apresenta a situação da filosofia no Brasil como uma luta entre uma tendência "democrática", representada pelos autores do volume, e uma tendência "autoritária", onde estão reunidos os adversários políticos. Eu publiquei também em Paris, nos Cahiers critiques de philosophie da Paris VIII, uma réplica a esta publicação ${ }^{6}$, diante do que eu considerava uma versão tendenciosa da complexa situação da filosofia no Brasil. Meu artigo de Paris é muito abrangente e seria inútil reproduzi-lo aqui na íntegra; vou comentar apenas um momento específico do mesmo, entre as páginas 64 e 72, onde eu analiso um texto de Marcelo Carvalho, Passado e presente na filosofia no Brasil, no qual se concentram melhor meus pontos críticos.

Sob a perspectiva dominante exposta neste artigo, e em quase todo o resto do volume, a filosofia começa propriamente no Brasil nos anos 30, com a recepção das "missões francesas" e a fundação da USP. Isto significa que todo o passado filosófico luso-brasileiro, desde o padre

\footnotetext{
6 Ver na bibliografia as referências desta publicação e de minha réplica.
} 
Vieira até Mário Ferreira dos Santos, deixa de existir (CABRERA, 2016, p. 64) O autor coloca a consolidação do ensino da filosofia nos anos 60 como uma luta contra a ditadura militar, uma conquista do espírito crítico contra o autoritarismo. Eu digo em meu texto-réplica que este relato soa estranho sendo que a filosofia que começa a se consolidar nas academias brasileiras naquela época é uma filosofia altamente técnica e instrumental, guiada pelo espírito francês e alemão, de corte nitidamente erudito, filosofia que nunca os militares poderiam ter visto como um perigo; antes pelo contrário, o atual sistema de estudos filosóficos se gesta precisamente nesse período (CABRERA, 2016, p. 65). Não sabemos se essa filosofia atacou alguma genuína fonte de autoritarismo, mas, certamente, ficou muito aquém de uma postura efetivamente crítica diante do que estava acontecendo no país. É evidente que um genuíno foco crítico teria sido destruído de imediato.

O autor do artigo coloca uma dicotomia na situação da filosofia brasileira; ele identifica dois grupos interessados na modernização e desenvolvimento do país, um grupo "democrático" e outro "autoritário". A visão autoritária estaria ligada com um conceito forte de nação e de uma cultura nacional, ideias ligadas em geral ao fascismo; enquanto que os democráticos são universalistas, comprometidos com um pensamento dirigido à humanidade, uma atitude nitidamente iluminista diante da qual as posturas contrárias ficam mergulhadas no obscurantismo. O autor coloca o ISEB, Instituto Superior de Estudos Brasileiros, como seguindo essa tendência nacionalista autoritária, mas, curiosamente, enquanto os militares fecharam o ISEB poucos dias depois de assumir o governo, a USP, segundo o próprio autor admite, foi preservada, apesar de severas restrições que não impediram a consolidação do sistema hoje hegemônico de produção de filosofia (CABRERA, 2016, p. 67).

O autor admite que essa concepção institucional da filosofia - uma concepção técnica, instrumental, erudita e eurocentrada - foi o resultado vitorioso de uma luta política (CABRERA, 2016, p. 68), e não algo surgido de um consenso. Neste momento de seu texto, o autor menciona Miguel Reale (1910-2006) como representante manifesto da "visão autoritária" e aqui se deixa ver claramente este curioso pingue-pongue onde as duas partes veem a outra como totalitária e antidemocrática. A menção de Miguel Reale é, pelo menos, curiosa, desde que este pensador - prolífico autor de um pensamento de certa projeção internacional - tem se posicionado ao longo de sua vida quase centenária contra diversas formas de autoritarismo, sendo ele mesmo vítima de uma de suas formas quando, no final dos anos 70, um texto de sua autoria foi censurado pelas autoridades universitárias por motivos políticos, abertamente declarados ${ }^{7}$.

Segundo a história oficial transmitida pelos autores do volume, a concepção da filosofia como "pesquisa", afirmada na concepção dita democrática do desenvolvimento, se encaminha para a criação do Sistema de Pós-graduação em Filosofia seguindo um modelo de análise rigorosa de textos, caracterizada pela diversidade de abordagens e tendências filosóficas. $\mathrm{O}$ autor afirma que este pluralismo teórico dificilmente poderia ter sido instaurado se a versão autoritária do desenvolvimento - personificada, segundo ele, por Miguel Reale - tivesse triunfado. Deixando de lado a temeridade contrafatual de imaginar "o que poderia ter acontecido se...", este "pluralismo teórico" do sistema atualmente vigente é mais aparente do que real, se pensamos na concentração quase exclusiva dos estudos filosóficos em fontes europeias de pensamento deixando de lado todo o pensamento africano, asiático e latino-americano, incluído o brasileiro. O que a situação hegemônica denomina de "pluralismo teórico" se refere unicamente à diversidade de correntes europeias de pensamento, difundidas por experts brasileiros devidamente treinados nos moldes franceses e alemães. Pensadores fora do molde institucional, e

\footnotetext{
${ }^{7}$ Este penoso evento foi narrado em ritmo de novela por Antonio Paim em seu livro Liberdade Acadêmica e Opção Totalitária.
} 
de tendência conservadora, como Mário Ferreira dos Santos ou Vilém Flusser são considerados apenas como "filosofistas" amadores à luz dos critérios da atual "filosofia profissional".

Já em meu Diário de um filósofo no Brasil reproduzi um depoimento do professor José Arthur Gianotti sobre Vilém Flusser onde se diz com todas as letras que a rejeição do pensador tcheco por parte do establishment da filosofia brasileira daquela época foi marcadamente política. Gianotti declara que, naqueles tempos

[...] os campos ideológicos estavam muito bem definidos" e "...o fato de certas pessoas terem vinculações com o nazismo, o fascismo e com a direita, para nós era um obstáculo a uma aproximação e havia, nitidamente, já uma separação [...]". Isso prejudicava o perfil de Flusser "num momento que para nós o perfil político era antes de tudo o mais importante [... ] (CABRERA, 2013, p. 77-78).

Isto implica, de maneira bem plausível, que o que vai importar primordialmente de um filósofo não será o valor de sua obra, a qualidade de seus argumentos ou o brilho de suas intuições, mas qual é seu perfil político; ele será visualizado e ouvido apenas se esse perfil for politicamente aceitável. A isto eu costumo denominar "pensar por credenciais". A partir daí, nas discussões filosóficas não se procura primordialmente a verdade que possa estar sendo transmitida pelo adversário, mas apenas vencê-lo no pressuposto dificilmente sustentável de que absolutamente nada do que o adversário político dizer pode ser verdade.

\section{Encontros com o Inominável}

Aquela atitude de recusa radical a que antes me referi, a negação de algo que não precisa ser conhecido para ser rejeitado, se apresenta claramente no atual panorama filosófico brasileiro no caso de uma figura muito especial: Olavo de Carvalho, um objeto de rejeição muito mais expressivo e contundente que Miguel Reale e outros pensadores conservadores. A rejeição absoluta passa inclusive pelo processo de nomeação; não nomear esta figura intelectual a risco de dar-lhe uma importância que não tem. Isto me fez lembrar, de imediato, à proibição dos argentinos de pronunciar a palavra "Perón" após a revolução de 1955. Era nome tabu, como se a mera menção do nome tivesse um poder instaurador a ser evitado de qualquer forma. O poder mágico dos nomes.

Olavo de Carvalho, pelo que me consta, não é lido pelos integrantes da esquerda, tal como caracterizada sumariamente na seção 1 deste artigo. Não que tenha sido lido e depois rejeitado, não se trata de uma não leitura qualquer; ele não deve ser lido, não se deve perder tempo lendo seus livros, nada do que ele escrever pode interessar. Esta atitude fica bem resumida na afirmação atribuída a uma figura da filosofia brasileira que teria dito em algum lugar, referindo-se a OC: "Não li e não gostei". Novamente parece constatar-se aqui uma primazia das emoções sobre os argumentos, já que é probabilisticamente quase impossível não encontrar absolutamente nada de valor num texto se nossa leitura for norteada por argumentos; as rejeições globais e totalmente certeiras parecem mais guiadas pelas emoções. Do ponto de vista estritamente argumentativo, este tipo de rejeição pareceria ser um caso claro do que os lógicos informais chamam "falácia genética" (às vezes vinculada com o "envenenamento da fonte") (PIRIE, 2008, p. 74; 107): impugnar tudo o que for dito por alguém - ou por uma instituição, ou sociedade, ou país - apenas por ter-se originado dessa fonte, com independência dos conteúdos. Este argumento nem sempre é falacioso, mas se transforma em falácia quando o valor do argumento é ponderado de acordo com a fonte da qual surgiu em lugar de ser julgado pelos seus méritos. 
A falácia fecha a possibilidade de que, mesmo uma fonte duvidosa possa gerar, alguma vez, um bom argumento.

Eu devo dizer em primeiro lugar que perdi para sempre a chance de rejeitar OC a priori, pois já fui leitor de, pelo menos, sete de seus livros. Muito pouco, dado o caráter prolífico deste autor, demasiado para seus detratores. Com estas leituras eu estou agora tristemente condenado a rejeitar as suas ideias - e elas são particularmente rejeitáveis, pelo menos desde a minha própria filosofia - no nível racional dos argumentos, não mais no patamar das emoções imediatas, sejam de amor ou de ódio. Pois é interessante observar que seus partidários costumam ser tão incondicionais e taxativos quanto seus detratores; Olavo de Carvalho é uma figura elevada ao nível de gênio e de primeiro filósofo brasileiro ou rebaixada ao mais miserável escalão da degradação do pensamento por parte de seus inimigos. Talvez isso seja também devido a sua personalidade multifacetada, que vai desde a imprecação desmedida até a instigante análise cultural. De qualquer modo, alguém capaz de despertar tais paixões não parece ser uma figura insignificante ou medíocre, além de discordâncias ou de acordos. Mesmo o considerado nefasto pode ser apesar de tudo, incontornável.

Devo dizer também que a ideia de uma rejeição sem ter lido, me parece, pelo menos numa primeira visão, inaceitável em filosofia. Rejeitar as ideias de um autor sem tê-las lido na fonte constitui um escândalo hermenêutico, com total independência de quem seja o autor. Não se pode falar do que não se conhece, e isto tem sido inclusive um valor profissional muito zelosamente observado na comunidade brasileira de filosofia. Uma rejeição que surge da recusa a sequer tomar conhecimento do objeto da rejeição constitui algo muito mais forte do que o famoso elogio gadameriano do preconceito na empreitada hermenêutica. Se a partir de agora podemos falar - bem ou mal ${ }^{8}$ - de um autor sem tê-lo lido, existe o risco de podermos estender esta metodologia a qualquer outro autor; ou deverão apresentar-se argumentos para que, nesse caso especial, o conhecimento do autor rejeitado possa ser legitimamente dispensado.

O que aqui mais preocupa é que se essa atitude não for devidamente caracterizada e justificada, ela pode, a princípio, ser generalizada a qualquer um que escreva sobre filosofia. $O$ que deveremos fazer para que, a partir de agora, essa curiosa regra anti-hermenêutica baseada no "não ler e não gostar" não seja aplicada a qualquer um de nós? Onde poderemos encontrar a justificativa racional da decisão sobre quem tem ou não tem as credenciais legítimas para filosofar, ganhando assim o gracioso direito de ser demolido somente após cuidadosa leitura? Até para fundamentar um absurdo - a rejeição de algo sem conhecê-lo - se precisa de argumentos, eis o paradoxo. Salvo que a filosofia se transforme numa galeria de aceitações e rejeições emocionais, de puras manifestações de amor e de ódio.

Durante muito tempo foi possível manter esta atitude de recusa radical, de simplesmente ignorar Olavo de Carvalho. Nos últimos anos, entretanto, dada a importância que adquiriu a sua figura nas médias e nas esferas do governo e ao imenso sucesso de seus livros e cursos on line, a sua rejeição radical tornou-se bastante mais difícil e forçada, embora essa mesma atitude fosse, em linhas gerais, mantida. Uma figura que tem essa presença marcante na sociedade não pode continuar, simplesmente, sendo ignorada, inclusive por aqueles que pretendem neutralizar a sua influência. Ignorá-lo não parece uma boa estratégia política, assim como - para usar a frase de um ex-aluno meu - não seria boa estratégia sanitária a de um médico que tentasse combater um vírus recusando-se a estudá-lo. Silêncios e omissões são espaços vazios que estão aí para qualquer um ocupar, e quando um barulho se tornou ensurde-

\footnotetext{
8 No livro Conversas com filósofos brasileiros, Gerd Bornheim afirma sobre Marilena Chauí: "O seu livro sobre Espinosa, que não li e não vou ler, é muito bom!" (ARMIJOS, 2004, p. 69).
} 
cedor resulta grotesco ver toda uma plateia se recusando a tomar conhecimento do fenômeno olhando para outro lado. Suponho que a comunidade filosófica brasileira já atingiu um nível de maturidade suficiente que lhe permita estudar qualquer autor sem se deixar contaminar pelas suas ideias e atitudes. Ler Saint-Exupéry não vai nos tornar aviadores.

Por minha parte, devo dizer que discordo da maior parte do que Olavo de Carvalho afirma em seus textos sobre os mais variados assuntos, e que seria muito difícil para um filósofo como eu - pessimista, antinatalista, pluralista, relativista, não religioso, preocupado com as desigualdades sociais e com a preservação das culturas indígenas, que escreve sem brilho e tem horror de palavrões e insultos - concordar com ele em alguma coisa. Mas desde quando a discordância foi motivo para não ler?

Por isso eu achei salutar que alguns professores de filosofia rompessem aparentemente este silêncio impossível. Num texto chamado Quão obscurantista é o emplasto filosófico de Olavo de Carvalho?, do professor Daniel Pérez, da Bahia, publicado em 2019, o autor - auxiliado por outros dois especialistas - trata de uma apropriação que ele considera errada que OC teria feito da filosofia de Kant, especificamente de seu famoso texto sobre o que é ilustração. O sistema responde, assim, num âmbito onde se sente bem à vontade: a análise de textos. Na verdade, para o que estou tentando mostrar neste artigo, o conteúdo desta discussão é de interesse menor, mas sou obrigado a mencionar alguns pontos do mesmo para poder analisar o que realmente me interessa.

Algumas das ideias em discussão nesse artigo são as seguintes: Kant afirma que não se pode apreender filosofia porque a filosofia não está dada; e supondo que estivesse dada, ninguém seria filósofo simplesmente por apreendê-la. Trata-se de pensar por si mesmo. $\mathrm{O}$ autor do artigo acha que OC se apropria desta ideia erradamente, pensando, por um lado, que a filosofia já está dada, e, por outro, que ele interpreta esta afirmação de Kant como se cada um pudesse pensar como bem entender, quando, na verdade, Kant se referia a um pensar dentro de uma comunidade e em interação com ela. Pensar por si mesmo não é pensar sozinho. Além do mais, segundo o autor do artigo, OC ignoraria totalmente o contexto histórico dentro do qual a reflexão kantiana sobre iluminismo é feita, a unificação da legislação, as relações entre igreja e Estado e o exercício da soberania popular na democracia representativa.

Por não entender esse contexto, OC equivocadamente atribui uma contradição ao filósofo alemão. Neste ponto, o autor comenta:

[...] quando encontramos uma contradição em um grande filósofo, o mínimo que se espera de nós é que leiamos o texto algumas vezes, porque muito provavelmente o equívoco está no nosso lado, fomos nós que não entendemos. Com Olavo é exatamente isto que se passa; ou não, talvez seja proposital.

Na parte mais ousada da sua abordagem, OC tece considerações acerca das relações de Kant com o cristianismo, com a figura de Jesus e com fenômenos contemporâneos como o terrorismo, saltos inferenciais - segundo o autor - claramente absurdos e deturpadores que não podem levar-se a sério.

A pergunta inicial aqui - indo além da matéria em disputa - seria como legitimar a fonte de uma autoridade capaz de estabelecer leituras corretas e incorretas de filósofos, de recolocar a verdade e afastar os erros num terreno tão escorregadio e complexo como a análise de um texto filosófico clássico. Apontar "erros de leitura" de um filósofo é sempre possível, todo argumento admite contra-argumentos; muitas leituras de um mesmo texto estão sempre disponíveis. Em filosofia temos apenas leituras, jamais podemos estar diante do "Kant em si" (ou de qualquer filósofo "em si"), de uma maneira não afetada por perspectivas; quem poderia ter a certeza de saber "o que realmente Kant disse" ou para declarar que a leitura do outro está er- 
rada ${ }^{9}$, pelo menos de uma forma que não possa ser respondida pelo autor se ele tivesse a oportunidade de fazê-lo? Não estaremos estabelecendo legitimidades incontestáveis acerca de quem está ou não está habilitado para falar sobre um autor ou uma questão filosófica?

Entretanto, o que mais preocupa é que a crítica não denuncie apenas um erro de leitura, mas um total absurdo. Algumas expressões que se usam: "são tantos os absurdos ditos por OC sobre Kant, que chega a ser difícil comentar", "Não que Olavo de Carvalho ofereça uma interpretação. Não. O que ele oferece é uma simples e pura falsificação, afirmações absurdas que não encontram nenhuma sustentação", etc. O fenômeno que quero apontar é que a outra parte não é vista apenas como falsa ou errada, mas como absurda, como algo que nem vale a pena levar a sério. Este é o específico tipo de rejeição que me interessa tentar de entender aqui.

Desde a minha concepção da filosofia, exposta muito antes da atual situação (CABRERA, 2013, p. 20-27), não parece, a princípio, errado utilizar um filósofo além do que ele quis dizer literalmente (se é que esta "literalidade" pode sequer ser detectada), nem apontar contradições mesmo num grande filósofo. Na citação anterior podemos ver essa total submissão ao autor consagrado tão típico da filosofia institucional: se encontrarmos uma contradição num "grande filósofo" o erro deve ser nosso. Por outro lado, se alguém não pretende fazer uma exegese de Kant, mas um uso livre desse filósofo para seu próprio pensamento, correndo todos os riscos, certamente que a sua afirmação será absurda se apresentada como algo que Kant mesmo teria supostamente afirmado. Se medíssemos Heidegger com a mesma vara, seu livro Kant e o problema da metafísica deveria ser considerado totalmente absurdo. E os saltos inferenciais de Olavo de Carvalho ficam como jogos de criança ao lado dos de Derrida ou Zizek ${ }^{10}$. Se alguém, coerentemente, considera Heidegger, Derrida e Zizek como charlatães, OC parece bem acompanhado. É truísmo afirmar que Heidegger foi um péssimo comentador e que Olavo de Carvalho é um péssimo professor uspiano.

O que eu vejo em textos como este do professor Pérez é que ele apresenta elementos muito relevantes para entabular uma discussão filosófica acerca das ideias de Kant sobre iluminismo, cristianismo, religião e política, e - num plano metafilosófico - sobre os usos e abusos de um filósofo quando fazemos filosofia. Os "absurdos" ficam por conta das leituras e seus pressupostos.

Um segundo cenário deste acidentado diálogo entre OC e o sistema filosófico vigente aparece num livro do professor Ruy Fausto chamado Caminhos da esquerda no qual o autor dedica cinco páginas a Olavo de Carvalho no capítulo 2 da obra, "A direita no ataque", o que me pareceu uma abertura interessante e promissora de diálogo. O texto é sumamente crítico apesar de que o autor concede que o discurso de OC "não exclui um trabalho de ordem mais analítica" (FAUSTO, 2017, p. 47) e que "[...] de vez em quando topamos com algum desenvolvimento interessante [...]" (FAUSTO, 2017, p. 194). Em seu texto, o professor Fausto se ocupa em acentuar os aspectos mais impopulares de OC, a sua violência verbal, suas opiniões conspiratórias sobre Obama, seus insultos e palavrões (FAUSTO, 2017, p. 47) e suas "pérolas de ódio" (FAUSTO, 2017, p. 49) ${ }^{11}$.

\footnotetext{
9 Ver meu antigo texto Por que não agrado aos rebeldes e meus trabalhos mais recentes sobre uma abordagem negativa da argumentação, na bibliografia deste artigo.

${ }^{10}$ A ideia de que a ideologia de gênero está vinculada com o fenomenismo kantiano é pelo menos tão esdrúxula quanto a ligação que Zizek faz entre a ideologia e a semântica de Kripke. Trata-se de ver quão caridosos estamos dispostos a ser. Alguém poderia aceitar que a ideia de que a realidade que vemos não é a "coisa em si" leva para a ideia de que a sexualidade não possui uma realidade em si, mais ou menos da mesma forma que alguém poderia aceitar que as ideologias apontam para suas vítimas seguindo a lógica dos designadores rígidos de Kripke. Aqui teríamos que dispor de um "absurdômetro" que nos permitisse desempatar absurdos. Se uma dessas coisas é considerada absurda e a outra não, teremos aqui novamente um caso de "pensar por credenciais".

11 O recurso da não nomeação dos malditos é bastante engraçada no final do Apêndice 1 do livro, onde o professor Fausto utiliza
} 
Na parte mais argumentativa de seu texto, ele apresenta desacordos de leitura sobre as relações de Marx com Epicuro e sobre a Lógica de Hegel, da qual, segundo o autor, OC não entendeu nada (FAUSTO, 2017, p.193-194). As observações do professor Fausto sobre as interpretações olavianas desses autores, assim como as suas réplicas às críticas de OC contra o que ele chama de "filosofia uspiana" (FAUSTO, 2017, p. 48-49), são procedentes e bem formuladas, mas, de novo, elas são adequadas para entrar numa discussão filosófica sobre esses autores e questões mais do que para alicerçar uma rejeição total e absoluta do adversário como algo absurdo. Acredito haver alguma diferença filosoficamente importante entre discordar da teoria de uma conspiração islâmica internacional e discordar na interpretação da Wesen de Hegel; concedamos que custa menos esforço considerar "absurdo" o primeiro que o segundo. Visto de um ponto de vista argumentativo, algo que parece absurdo numa perspectiva poderá tornar-se razoável em outra. A Lógica de Hegel parece um objeto cultural demasiado escorregadio como para conferir alguém a capacidade de decretar ignorâncias ou habilitar competências hermenêuticas com tanta certeza.

Mas esta estratégia de considerar totalmente absurdas as ideias e atitudes da outra parte, e não simplesmente como falsas, é também vastamente utilizada por Olavo de Carvalho em suas considerações contra uspianos, a pesar de que, em linhas gerais, ele parece ter lido mais filosofia do adversário do que vice-versa. Mas quando passa a discuti-los não entabula com eles uma discussão filosófica na qual as duas partes teriam argumentos para um debate, mas ele simplesmente denuncia as "absurdidades" e desonestidades de seus adversários. Por exemplo, ele escreveu um texto onde discute o livrinho Que é ideologia?, da professora Marilena Chauí, onde ela sustenta que as coisas deixam de ser coisas para transformar-se em algo que já não é mais coisa, enquanto OC sustenta que essas coisas não deixam de ser coisas pelo fato delas representarem simbolicamente algo mais do que meras coisas. OC diz que a postura da Chauí está cheia de "absurdidades", "erros e confusões", que ela pratica "a técnica do absurdo compactado", sustentando teses "assustadoramente pueris" (CARVALHO, 1999).

Mas no plano estrito dos argumentos, ambas as teses sobre as coisas podem ser sustentadas e nenhum dos lados incorre em completo "absurdo". Certamente, a professora Marilena teria fôlego e cartuchos para responder a cada uma das objeções de Olavo de Carvalho, se ela aceitasse alguma vez dialogar com ele. Igualmente, quando discute ideias do professor Porchat sobre a diversidade de filosofias e ceticismo, OC coloca a questão de até que ponto pode-se supor uma "continuidade" da história da filosofia como para poder colocar todos os sistemas numa estante e compará-los. Mas a ideia do professor Porchat não é "absurda" ou descabida; como máximo, pode ser uma ideia falsa, e nunca num sentido absoluto (nada é falso ou absurdo desde todas as perspectivas, salvo, talvez, para Deus); no plano humano finito, é claro que é possível sustentar ambas as coisas, que a história da filosofia é contínua e que ela é descontínua, existindo argumentos para ambos os lados; trata-se de uma discussão em curso e não de uma situação na qual uma das partes falaria desde a certeza da verdade e a outra ficaria atolada no total absurdo.

Pareceria que cada filósofo esquece as suas premissas no momento de tirar as conclusões, que passam a ser vistas como absolutas; não mais se percebe a sua total dependência de seus próprios pressupostos. Cada filósofo apaga as suas próprias pegadas, como o assassino que tenta cometer o crime perfeito. (O crime perfeito em filosofia seria fazer uma filosofia sem nenhum pressuposto). Eles têm a forte impressão de estar apontando para absurdos total-

expressões como "Da primeira figura que comentei" e "o mesmo senhor" (FAUSTO, 2017, p. 152), "o segundo ideólogo", “a terceira figura" (FAUSTO, 2017, p. 153), para não ter que mencionar os nomes dos autores da direita. 
mente objetivos da outra parte, sem conseguir ver que sem os pressupostos assumidos os tais absurdos não apareceriam por si sós. Mas o realmente curioso (e assustador) é que toda vez que, em grupos ou discussões, tentei pôr de relevo que ambos os lados utilizam a mesma estratégia argumentativa - colocar-se no lugar da verdade e ver a outra parte como absurda, em lugar de simplesmente falsa - invariavelmente cada uma das partes reage iradamente e me acusa de ofendê-la por compará-la com a parte contrária. Cada parte fica irritada quando é igualada com a outra, apesar dos exemplos mostrarem que as atitudes são muito semelhantes; e cada uma delas alega ter apontado para absurdos e desonestidades completamente objetivas da outra parte.

\section{Olavo de Carvalho como sintoma}

Até aqui vemos que também no âmbito da filosofia a polarização esquerda versus direita se apresenta com toda a sua força opositiva e de rejeição mútua radical, apesar da filosofia ter sido, tradicionalmente, o campo dos argumentos racionais e a busca de uma vida sábia e equilibrada. Mas dentro desse âmbito, aparecem também diversas formas de entender as atividades filosóficas. Uma diferença importante no atual panorama intelectual latino-americano tem sido a diferença entre um filosofar fortemente institucional, centrado na análise de textos, e um filosofar mais autoral, tentando pensar a realidade com categorias próprias. Quero examinar aqui como estas duas formas de entender as atividades filosóficas se inserem na disputa acirrada entre direita e esquerda.

Olavo de Carvalho tem criticado em vários textos o tipo de filosofia oriundo da USP declarando que, ao longo de décadas, o Sistema de Pós-graduação brasileiro não produziu pensamento original de projeção internacional. Aqui encontramos algumas de suas afirmações mais austeras: "Ao contrário do que reza a superstição uspiana, a filosofia, é claro, não tem como finalidade essencial a produção de textos [...] Em filosofia, o fundamental é a descoberta, a teoria, a intuição filosófica obtida, da qual o escrito será apenas o documento mais fiel ou menos fiel" (CARVALHO, 2012, p. 130-131; 115). “Cultura filosófica é o que um sujeito sabe de filosofia sem ter de assumir a responsabilidade pessoal de filosofar" (CARVALHO, 2012, p. 133). "Sozinha, a cultura filosófica, mesmo em doses cavalares, não fará de você um filósofo, apenas um erudito" (CARVALHO, 2012, p. 134) ${ }^{12}$. Em textos de 2001 onde ele comenta o livro A Filosofia e a visão comum do mundo do professor Oswaldo Porchat, OC escreve:

Então você não está interessado em nenhuma daquelas filosofias como conjunto, mas apenas na contribuição que elas poderiam dar para a elucidação da questão que você está colocando. E eu estou persuadido de que é assim que se estuda filosofia [...] (CARVALHO, 2001, p. 14).

Estes pensamentos sobre o que significa fazer filosofia, e especificamente sobre as diferenças entre filosofar e estudar filosofia, são muito semelhantes aos que já apareciam em escritos tardios de Schopenhaueur, incluídos em "Parerga e Paralipomena"13, à quem OC nunca se refere, que eu saiba. Também Heidegger tem afirmado ideias semelhantes em sua Introdução à Filosofia (HEIDEGGER, 2009, p. 5). Estes são dois filósofos reconhecidos no panteão de pensadores oficiais, mas também são pensamentos muitas vezes expostos por Ortega y Gasset em

\footnotetext{
12 Também se podem consultar vários artigos incluídos em O imbecil coletivo I: Filosofia Uspiana, ou: Tremeliques de Mlle Rigueur ( $\mathrm{p}$. 211) e a Carta de um filósofo a Papai Noel (p. 503).

${ }^{13}$ Especialmente os textos Sobre a erudição e os eruditos, Pensar por si mesmo e Sobre a leitura e os livros.
} 
vários momentos de sua obra. Ora, muitos dos que rejeitam de plano as ideias de OC sobre filosofar original poderão aceitá-las, ou, pelo menos, tomar conhecimento delas, quando ditas por Schopenhauer ou Heidegger, ou mesmo por Ortega. Isto fornece um bom exemplo do "pensar por credenciais" de que antes falávamos: as mesmas ideias poderão ser aceitas ou lidas com atenção quando ditas por alguém e rejeitadas quando ditas por outro. (É claro que ambas as partes negarão tratar-se "das mesmas ideias") ${ }^{14}$. Na minha portentosa ingenuidade, eu pensava que se alguma ideia fosse valiosa continuaria sendo valiosa quando dita por um pensador menor ou por alguém que nem consideramos pensador; e se a ideia for absurda, o será mesmo quando dita por Schopenhauer, Heidegger ou Ortega y Gasset.

Nesta linha de pensamento, talvez possa ser promissor ver OC como sintoma da situação atual da filosofia no Brasil. Pois é possível inferir, a partir da sua mútua rejeição radical, as formas como a filosofia foi de fato entendida, produzida e avaliada no Brasil nas últimas décadas. Se poderia dizer que a filosofia é feita no Brasil contra tudo aquilo que Olavo de Carvalho representa. Já em 2014, quando comecei a pensar pela primeira vez neste assunto, eu tecia algumas hipóteses elementares acerca desta rejeição, que não se baseava na contestação de algum conteúdo doutrinário de ideias, pois isso suporia algum conhecimento mínimo de suas obras. Não, a rejeição era mais externa, alheia aos conteúdos específicos de seus textos; era a rejeição de uma atitude, de um estilo, de uma personalidade, de uma postura de política cultural. As minhas cinco hipóteses de trabalho eram naquela época as seguintes: (1) Olavo de Carvalho não está institucionalmente habilitado para filosofar, (2) não analisa textos, (3) se pretende livre pensador com filosofia própria ${ }^{15}$, (4) é popular e socialmente influente e (5) não cultiva qualquer tipo de cordialidade. A minha ideia é que este tipo de escritor filosófico deve ser totalmente inassimilável para o sistema atual de produção de filosofia profissional, sem que seja necessário ler uma só linha de seus escritos.

Mas é precisamente por isso que ele se transforma em sintoma da filosofia no Brasil, pois essas cinco características da figura filosófica de OC apontam indiretamente para as características do corpo que cria o sintoma. Por simples oposição, se poderia dizer que a filosofia produzida pelo sistema vigente se caracteriza pelos seguintes elementos: (A) É um projeto institucional que apenas reconhece o que ele mesmo produz e reproduz; (B) Que se desenvolve fundamentalmente a través de análise e interpretação de textos seguindo métodos exegéticos sofisticados; (C) Que desconfia de qualquer pretensão autoral e de originalidade como sendo arrogante e injustificada; (D) Que é exposta em claustros e espaços seletos; (E) Num estilo de exposição austero, comedido e cordial $^{16}$.

\footnotetext{
${ }^{14} \mathrm{O}$ saudoso professor Oswaldo Porchat, na última parte de seu famoso "Discurso aos estudantes da USP sobre a pesquisa em filosofia" escreveu, referindo-se aos alunos formados pela sua geração: "[...] foram educados (ou deseducados) no temor malsão da criatividade filosófica, o que foi muito mau. Sob esse aspecto, nós, os mestres deles, miseravelmente falhamos". (Este texto está reproduzido em De Souza (2006). O professor Porchat não perdeu um ápice de seu prestígio por declarar isso, apesar dele mesmo avisar, algumas páginas antes, que "Tenho plena consciência de que estou quase pisando aqui num terreno minado, que minhas palavras podem horrorizar os bem-pensantes". Mas talvez outro pensador que repetisse exatamente a mesma ideia, com as mesmas palavras, seria crucificado ou, pior ainda, totalmente ignorado. As minas não explodem para todos. Nunca como neste momento é útil distinguir entre as dimensões semântica e pragmática da linguagem; as "credenciais" são eminentemente pragmáticas; a mesma letra semântica pode estar ou não legitimada pela comunidade filosófica.

${ }^{15}$ Ronald Robson escreveu uma longa monografia chamada Conhecimento por presença. Introdução à filosofia de Olavo de Carvalho, ainda inédita, onde tenta expor este livre pensamento.

${ }^{16} \mathrm{O}$ sistema (A)-(E) não apenas rejeita ou ignora figuras como a de Olavo de Carvalho, que representa a negação de todas essas características, mas também rejeita ou ignora outros pensadores que foram explícitos críticos do sistema hegemônico e que satisfazem pelo menos uma parte das características (A)-(E). Roberto Gomes (na Crítica da razão tupiniquim), Vilém Flusser (em Fenomenologia do brasileiro), Gonzalo Armijos (em De como fazer filosofia sem ser grego, estar morto ou ser gênio) e Julio Cabrera (no Diário de um filósofo no Brasil e em O projeto institucional da filosofia no Brasil e a inexistente Escola de Brasília) são quatro intelectuais cujas críticas jamais foram respondidas por nenhuma figura importante da filosofia institucional, apesar de alguns desses quatro críticos terem titulação acadêmica em filosofia, Currículo Lattes, publicações no Qualis, participação em congressos Anpof,
} 
Mas neste ponto de nossa reflexão começamos a dar-nos por conta de algo realmente surpreendente - e ao mesmo tempo óbvio - a respeito das relações entre essas duas concepções de filosofia e o conflito entre Direita e Esquerda, que tentarei explicar na próxima e última seção deste artigo.

\section{Para uma ontologia do conflito Esquerda versus Direita. O entrecruzamento trágico de dois dualismos e a liberação da filosofia}

\section{Prefácio para uma guerra total: do social para o ontológico}

A mútua atitude de rejeição sem sequer tomar conhecimento, ou lendo apenas para detectar absurdos, deve levar forçosamente a uma situação sem saída pacífica, como tentarei mostrar. Um bom exemplo de belicosidade são os textos de OC onde ele sustenta que não é possível discutir com esquerdistas

[...] como se fossem elegantes divergências acadêmicas [...] "Quando um sujeito insinua que vai me matar, ou me mandar para o Gulag, responder polidamente que não concordo muito com a sua proposta é dar-lhe ares de mera e inofensiva hipótese, quando na verdade se trata de um plano muito prático, muito material. [...] Luta armada, caramba, não é teoria filosófica: é matar pessoas. Sempre que discuto com esquerdistas, sei que estou discutindo com assassinos. Muitas vezes, assassinos adiados, mas no fim das contas sempre assassinos (CARVALHO, 2016, p. 286).

Segundo ele, não se pode fingir que estamos tendo uma mera "divergência de ideias" com aqueles que debatem planos para o nosso assassinato e sonham com a nossa morte.

Provavelmente textos deste teor sejam os que mais favorecem a atitude de não querer conhecer mais escritos de um autor que declara coisas como essas. Temos então, por um lado, um autor que não vale a pena ler, pois somente transmite absurdos; e, pelo outro, um autor que declara ser impossível qualquer diálogo com essas pessoas que decidiram não lê-lo. Trata-se de uma situação de rejeição mútua total, absoluta e irreversível: não se pode falar com esquerdistas porque são todos assassinos, e não se devem ler as obras dos conservadores (potencialmente fascistas) porque não podem conter nada de valioso para uma sociedade emancipada. Se o confronto não for de argumentos, mas de mútua rejeição absoluta, quase a priori ${ }^{17}$, não há qualquer esperança de que ambos sejam capazes de construir uma sociedade onde os dois lados possam conviver conflitantemente sem se destruir. Se a estratégia consiste em ignorar o que a outra parte escreve, ou proclamar que não há diálogo possível com ela, mas apenas defender-se e tentar de destruí-la antes de ser destruída por ela, gostaria que ficasse muito claro que essa atitude deve coerentemente levar para uma guerra total sem composições (não digamos conciliações) de qualquer tipo.

Essa guerra pode ser fria (uma espécie de "mostrar os dentes" para que a outra parte saiba que podemos destruí-la) ou quente, chegado o momento oportuno; mas, em qualquer

terem feito análises de textos e não utilizarem insultos nem imprecações para manifestar suas ideias. O que pode estar apontando para uma modalidade de exclusão intelectual muito além do fenômeno Olavo de Carvalho, que só teria servido para pôr de manifesto uma estrutura mais profunda e de maior alcance.

17 Com o "quase" gostaria frisar a diferença entre não ler em absoluto e ler apenas para detectar absurdos. Nos dois casos há exclusão total. A diferença é que, no primeiro caso, o absurdo seria tanto que nem permitiria o acesso ao texto, enquanto que, no segundo, o absurdo decorre de uma leitura sistematicamente desqualificadora, sem qualquer esforço de entendimento do que a outra parte está tentando dizer. 
caso, devem-se tirar corajosamente as conclusões dessa mútua atitude de total rejeição sem mediações: que os humanos não conseguiram edificar um projeto civilizador capaz de abranger toda a humanidade, mas que qualquer projeto de sociedade se alicerça na exclusão de uma parte da humanidade como não sendo merecedora de respeito, e à qual nem sequer se reconhece o direito a existir, não digo intelectualmente, mas nem mesmo fisicamente ${ }^{18}$. Esses projetos sociais simplesmente encenam a mesma luta que se apresenta em outras espécies animais, utilizando armas, textos, sistemas jurídicos e Internet em lugar de garras, dentes e secreções venenosas. Nenhum dos lados vai se deixar matar, ambos lutarão até o fim para instaurar a sua própria perspectiva no mundo e preferirão que o mundo mesmo exploda antes de ceder. Seria bom que "engajados" sartreanos de esquerda ou de direita reconhecessem abertamente a sua opção pela guerra total; isto já seria um grande passo. Se a rejeição do outro lado é total, absoluta e definitiva, o único caminho aberto é a guerra de destruição daquele que quer nos destruir; ganhar-lhe a dianteira e eliminá-lo antes dele nos eliminar.

Se assim são os termos, deixando de lado meias palavras e eufemismos (e nisto os insultos de OC podem resultar, afinal, mais esclarecedores dessa atitude de guerra total que os estilos cordiais), podemos supor que o conflito entre direita e esquerda é irresolúvel no plano político, porque, no fundo, se enraíza numa necessidade muito primitiva do conflito no qual a vida mesma consiste desde sempre, muito antes inclusive da invenção moderna da diferença entre esquerda e direita. Aqui o conflito político teria que buscar suas mais profundas raízes ontológicas, que é o plano que, desde o início deste texto, eu queria realmente atingir.

Nas Questões de Método, Sartre escreveu: “Aos marxistas de hoje só lhes preocupam os adultos; ao lê-los poderia acreditar-se que nascemos na idade em que ganhamos nosso primeiro salário" (SARTRE, 1970, p. 56-57, Tradução nossa). Esta observação pode ver-se como uma província de uma ideia maior: os humanos em geral (não apenas marxistas) acreditam que nascemos quando conseguimos ganhar um lugar dentro de alguma sociedade humana, quando somos identificados em espaços de ação social. Parafraseando Sartre, os humanos acreditam que nascem quando são reconhecidos como membros de uma família, quando aceitos no quartel, quando se formam na universidade ou quando conseguem um emprego. Como bom admirador de Freud, Sartre quis denunciar o esquecimento da infância por parte dos marxistas (essa infância que Sartre estudou em numerosas biografias que escreveu). Meu alargamento do escopo da frase de Sartre visa mostrar não o esquecimento da infância, mas o esquecimento do próprio nascimento. $\mathrm{Na}$ verdade, todos esses "nascimentos" sociais e institucionais fazem esquecer o nascimento, 0 fato bruto e brutal de termos sido lançados no mundo assimetricamente.

Pois antes que filhos, trabalhadores, estudantes ou cidadãos, somos simplesmente humanos numa situação primordial de desamparo e fragilidade, sujeitos a agressões de todo tipo, não apenas as dores sensíveis, mas também às numerosas formas de desânimo, desde o simples tédio até as mais graves depressões. A situação em que fomos colocados, num corpo que envelhece e definha cada dia, sujeitos a agressões sem fim, é profundamente desanimadora, e conseguimos levá-la adiante somente pela constante luta contra seus avanços. Dor e desânimo não são os únicos perigos, também temos que nos cuidar permanentemente dos outros, dos riscos de relacionamentos perigosos, do ódio, do preconceito, da exclusão e da perseguição, provocados por outros humanos também submetidos à dor e ao desânimo. Os humanos, pela sua fragilidade e desamparo, são obrigados não apenas a lutar pela sobrevivência, mas também a tentar dar-se um valor, uma autoestima sem a qual não será possível enfrentar as agruras da

\footnotetext{
${ }^{18}$ Como o soldado nazista no filme Vá e Veja (1985), de Elem Klimov diz para seus captores russos: "Vocês não deveriam existir; nem todas as nações têm direito ao futuro".
} 
vida $^{19}$. Parece evidente que, postos nessa situação de árdua sobrevivência e conflito, os humanos priorizem suas emoções de medo, receio, suspeita, ameaça e defesa do próprio corpo e da própria identidade, mais do que frios argumentos racionais ineficazes para enfrentar os atritos da situação primordial.

Essa situação humana tem sido sistematicamente ocultada - pelo menos na tradição cultural ocidental - por uma construção idealizada da vida humana, dando uma imagem do humano como ser racional, consciente, livre e responsável. Malgrado as diferenças entre tradições, houve sempre uma tentativa de absorção do ontológico por parte do ôntico, da situação estrutural pelo social e político, do inevitável por aquilo que pode ainda ser manipulado. Dentro desta situação de mal-estar estrutural os humanos começam a pensar que há algo de errado neles ou nos outros, nunca buscam o errado na situação mesma em que foram assimetricamente colocados. Para a vida se tornar suportável é fundamental ter um adversário que carregue com as responsabilidades de nosso mal-estar estrutural, alguém que tenha a culpa de não podermos viver a vida intensamente, alguém sem o qual todas essas coisas seriam superadas quando eliminado o obstáculo indesejado.

Nem sempre existiram "esquerda" e "direita" no discurso político. Como todo mundo sabe, esta distinção foi feita pela primeira vez no século XVIII. É claro que poderíamos transportá-la mais ou menos arbitrariamente para o passado e ver, por exemplo, Bartolomé de Las Casas como de esquerda e Ginés de Sepúlveda como da direita, e este anacronismo não seria totalmente absurdo. Pois, de certa forma, trata-se de uma oposição muito primitiva, que aponta para dois modos ontológicos de inserção num mundo que provoca dor, desânimo e agressões de todo tipo, e que nos obriga a uma indefinida tarefa de autovaloração e hetero-desvaloração. Podemos supor que essa oposição primitiva vai continuar existindo muito depois de que os termos, "esquerda" e "direita", tenham deixado de ser utilizados em discursos políticos. Significa que essa oposição não é algo que deva ser expresso forçosamente mediante esse vocabulário.

É evidente que humanos de direita e de esquerda partilham essa mesma situação humana provocadora de mal-estar, não de maneira eventual, mas estruturalmente, já desde o nascimento. Mas, por que isso não os aproxima? Se a situação estrutural agride e desanima, se ela obriga a dar-se um valor, a satisfazer desejos em espaços estreitos, a gerar fantasias reparadoras e absorver o ontológico para dentro do ôntico, estas operações não são feitas da mesma forma e com os mesmos conteúdos. Os humanos de direita e de esquerda são agredidos e desanimados por coisas diferentes, suas valorizações de si mesmos têm diferentes conteúdos e motivações, as suas fantasias têm direções diferentes, eles não temem as mesmas coisas, não se assustam nem fogem da mesma maneira nem absorvem o ontológico no ôntico da mesma forma. Eles apenas partilham a situação humana primordial, mas lhe conferem direções vitais diferentes. Suas frustrações não são as mesmas. As duas são atitudes de fuga diante de uma dura situação ontológica, mas elas pressupõem duas maneiras diferentes de assustar-se do real e de tentar se afastar dele. A situação estrutural partilhada não consegue vinculá-los, mas, pelo contrário, os enfrenta de maneira irreconciliável.

Os tipos de temporalidade que se precisa para manter vivas as tradições fundadoras que a direita aprecia e os que se precisa para tentar realizar uma sociedade utópica de esquerda são profundamente diferentes. As revoluções sociais não são colocadas na mesma temporalidade histórica que as tradições que moldariam persistentemente nossos comportamentos atuais;

\footnotetext{
19 Para uma descrição mais detalhada da situação humana primordial, ver: Cabrera (2018), Capítulo 1. “Valor da vida humana como reivindicação existencial".
} 
não são, pois, dois movimentos existenciais que estariam lutando por ocupar uma mesma temporalidade, mas duas formas de produzi-la. De forma semelhante, de ambos os lados há um humano tentando realizar seu destino dentro de uma vida que escoa e decresce numa árdua luta pela autoestima; mas de um lado temos um agente capaz de transformar radicalmente a realidade e do outro um ser fortemente consciente de suas limitações insuperáveis; eles produzem dois espaços diferentes de elaboração da finitude.

Ser no mundo de esquerda ou ser no mundo de direita representam, igualmente, duas formas de submeter-se à autoridade do outro: ou reivindicando uma individualidade irrenunciável ou aceitando ganhar uma identidade social através da luta. Um ser no mundo que se instala na linguagem como seu dono ou como seu súbdito, que fala diante de uma realidade que interpela e pede transformações, ou que nos insta a escutar com humildade o que ela tem a nos dizer. Um modo de ser que aproxima o céu da terra, tornando os deuses em entes interessados no humano ou outro modo que vê os deuses como lugar de encontro e recolhimento. São também duas formas de simbolizar a preocupação com a morte a través da tentativa de uma vida intensa; mas esta intensidade é concebida de maneiras diferentes: um humano de direita sente um profundo medo de perder a sua individualidade numa forma de vida coletiva enquanto que o maior medo de um humano da esquerda é morrer deixando o mundo sem ter tentado transformá-lo radicalmente.

Essas diferenças de inserção no ser e no tempo fazem com que dois tipos diferentes de fugas da situação terminal do ser se prejudiquem mutuamente. Mas esse conflito, seja qual for seu conteúdo eventual concreto, é operado numa complexa relação do ôntico com o ontológico; pois cada uma das partes em conflito, ao tempo que são feridas pela situação estrutural partilhada, passam a acreditar que seja a outra parte a geradora da frustração, a causa da dor e do desânimo, da sistemática insatisfação dos desejos, do incômodo e mal-estar do ser. A frustração estrutural de ser é atribuída por cada um dos lados ao outro; ambos pensam que a vida seria possível sem o obstáculo do adversário, e que ela é inviável nos termos do inimigo. Cada um dos lados pensa que a vida humana atingiria a sua plenitude sem os obstáculos colocados pelo outro, considerado nefasto e repulsivo.

Mas há ainda um último elemento ontológico, talvez o mais paradoxal de todos: os humanos, como quaisquer outros seres naturais, precisam de oposição e de luta para continuar vivendo e para sentir-se viver; para reforçar a sua autoestima precisam vencer resistências, derrotar, submeter. No viés ontológico começamos a entender que alguma oposição deverá existir, porque ela é necessária para viabilizar uma vida humana na situação primordial. Esquerda e direita são apenas rostos eventuais de uma oposição primária que mesmo gerando sofrimento é totalmente necessária para a economia ontológica dos humanos, para a dura administração de um ser declinante, desanimador e perigoso. Nesse sentido, os termos dessa oposição mortal, aquela que apenas pensa na eliminação da outra parte, se precisam mutuamente e, nesse sentido, se atraem. Pode-se dizer que, como encenações concretas desse conflito primordial inapagável, esquerda e direita se atraem intensamente, elas se precisam e constantemente estão se reinventando mutuamente para poder continuar coligindo. É evidente que este conflito não acabará jamais, mesmo quando não sejam "direita" e "esquerda" as suas figuras explícitas.

Aqui podemos visualizar melhor as raízes ontológicas daquela primazia do emocional sobre o racional, no encaminhamento para um lado ou para o outro do espectro político, tanto nas massas iletradas quanto na parte aparentemente mais esclarecida da população, incluindo seus filósofos. Essas opções políticas estão encravadas num poderoso desejo de vencer as resistências de um nascimento terminal decrescente e cheio de atritos, que constantemente in- 
comoda e limita e dentro do qual temos que realizar um ser incompleto e agredido, em espaços e tempos muito curtos de ação. As decisões não são norteadas primariamente por motivos racionais ponderados, mas por tentativas de fuga de sofrimentos sensíveis e morais insuportáveis para a autoestima e a sobrevivência. As opções políticas apenas fornecem conteúdos nômades para uma força vital que tenta não ser prematuramente devorada pelo tempo, pelo desgaste da finitude.

Diante deste quadro, começa a nascer o forte desejo - talvez politicamente ingênuo - de liberar a filosofia de todos esses horrores, do risco de que a filosofia mesma seja destruída na guerra total na qual foi colocada. (Ver seção 3). Mas remover a filosofia desse conflito insolúvel não significa levá-la para uma "pureza" neutra impossível, mas talvez para um novo tipo de militância política. Já no final deste artigo tentemos pensar melhor os termos desta liberação.

\section{Liberação da Filosofia?}

Um primeiro pensamento nesta direção seria o seguinte: no plano específico da filosofia, nem as críticas do sistema filosófico vigente contra Olavo de Carvalho (ou contra outros pensadores considerados "de direita", como Miguel Reale) nem as de Olavo de Carvalho contra a filosofia do sistema hegemônico parecem representar estritamente um confronto entre esquerda e direita tal como foram antes apresentadas.

Com efeito, percorramos rapidamente as características mencionadas na seção 1: tanto quem vê o mundo como uma construção cultural num movimento para o futuro como quem o vê como dado, em grande parte, pela natureza numa forma de retenção das tradições do passado; tanto aqueles que concebem o humano como um agente capaz de grandes transformações sociais quanto os que o veem como limitado e não confiável; tanto os que procuram uma solução radical das desigualdades quanto os que preferem reformas graduais, tanto internacionalistas quanto nacionalistas ${ }^{20}$, favoráveis a um Estado mínimo ou um mais intervencionista, religiosos tradicionais ou teólogos da liberação, os mais sensíveis às questões ecológicas quanto os mais insensíveis, todos eles poderiam a princípio partilhar a ideia de uma filosofia como projeto institucional ou de uma filosofia como empreitada autoral. Pelo menos num primeiro pensamento, nada parece haver em sua filiação política que deva incliná-los forçosamente na direção de uma ou outra destas duas concepções de filosofia.

Aqui temos dois dualismos que se entrecruzam: direita versus esquerda, filosofia institucional versus filosofia autoral. Parece total contingência que, na situação atual, um projeto institucional da filosofia coincida com o predomínio de uma intelectualidade de esquerda. Nas críticas de OC à filosofia da USP esta diferença não me parece clara: se existe para ele uma conexão, que eu não consigo ver, entre essa filosofia que não deu um único filósofo de renome internacional e o fato de seus cultores serem politicamente de esquerda. O projeto institucional da filosofia poderia ter sido erigido pela direita e seria igualmente criticável com os mesmos argumentos, por ser uma filosofia burocrática que não estimula a pensar por si. A princípio, no puro plano dos conceitos, não parece haver nenhuma ligação interna entre fazer uma filosofia institucional e burocrática e ser de esquerda ou de direita. A rejeição radical de OC por parte do

\footnotetext{
${ }^{20} \mathrm{Em}$ meu artigo Europeu não significa universal, brasileiro não significa nacional (2015) tentei mostrar que a questão de um filosofar autoral não está vinculada internamente à questão de um "filosofar nacional". Se houvesse tal vínculo, sim poderia traçar-se uma linha entre ser da direita nacionalista e ser partidário de um filosofar autoral, mas isso não se sustenta como tentei provar nesse texto.
} 
establishment não é operada pelo fato dele sustentar um projeto de filosofia autoral, contra a concepção institucional do pensamento dominante no Brasil. Ou seja, OC não é rejeitado por reeditar as metafilosofias de Schopenhauer, Heidegger ou Ortega. Trata-se de um confronto político cultural, fortemente carregado de afeto, entre duas atitudes diferentes e antagônicas de assumir as atividades filosóficas, o exercício mesmo do pensamento, mas nada há nestas características que as identifique como de esquerda ou de direita ${ }^{21}$.

Mas esta ideia, num segundo pensamento, poderia ser contestada. Em sua apresentação das duas tendências existentes na filosofia no Brasil, que ele considera como uma situação "esquizofrênica", o professor Paulo Margutti explica que enquanto o grupo oficial, ligado a CAPES e ANPOF se inclinaria mais para um filosofar de comentário exegético, os membros da tendência luso-brasileira, mesmo também se utilizando da exegese, tenderiam a acentuar mais o pensamento nacional e, com menos ênfase, a necessidade de um pensamento próprio (MARGUTTI, 2013, p. 3-4). Na mesma linha, no famoso livro Conversas com filósofos brasileiros, Miguel Reale, de tendência conservadora, aparece defendendo os esforços por um pensamento autoral próprio, enquanto que quase todo o restante dos entrevistados, em geral de filiação de esquerda ou centro-esquerda, defende, de uma forma ou outra, a ideia institucional da filosofia (ARMIJOS, 2004b, p. 10-17). Se não assumirmos dogmaticamente já de início o critério institucional do filosofar podemos perfeitamente reconhecer o valor de trabalhos filosóficos de autores brasileiros - natos ou adotados - como Vicente Ferreira Da Silva, Vilém Flusser, Mário Ferreira dos Santos e o próprio Reale, como mostrando meritórios esforços de filosofia autoral, mesmo sem a eficiência formal dos comentadores do outro grupo. Mas os quatro filósofos mencionados foram politicamente conservadores. E se pensarmos nos filósofos clássicos europeus que propugnaram um filosofar autoral, como Schopenhauer, Heidegger e Ortega, todos eles foram conservadores (e um deles nazista).

Este curioso panorama mostra que foi, de fato, a direita que deu pensadores autorais, e que filósofos da esquerda apoiam em sua maioria o projeto institucional da filosofia. O que não deixa de ser curioso porque o filosofar original e autoral é um projeto claramente emancipador, de política cultural liberadora, enquanto que a institucionalização do pensamento é um projeto conservador e colonizado. Seria mais plausível que a direita assumisse um projeto institucional e a esquerda um projeto emancipador. O que cabe aqui perguntar é se esta conexão entre a direita e o autoral, de um lado, e da esquerda com o institucional do outro, é apenas fato contingente, ou se, no plano dos conceitos, há algo que leve ao pensador de direita enquanto tal a assumir uma concepção autoral do filosofar, e se há algo no pensador de esquerda que, intrinsecamente, o conduza a favorecer a noção institucional. (Trata-se de uma situação parecida às relações entre Hegel e a Filosofia Analítica contemporânea: na época de Bertrand Russell, ambos eram incompatíveis, mas na época de Robert Brandom, Hegel e a Filosofia Analítica se encontraram; o que mostrou que não existia nenhuma incompatibilidade conceitual entre Hegel e a Analítica, mas apenas uma desavença de fato que, com o tempo, desapareceu).

Como não consigo ver nenhuma conexão conceitual firme entre ser de direita ou de esquerda, por um lado, e defender uma noção autoral ou uma noção institucional do filosofar

\footnotetext{
${ }^{21}$ Numa visão superficial, alguém poderia dizer que essa rejeição radical de OC por parte do establishment filosófico brasileiro proviria do fato de que uma pessoa sem nenhuma habilitação institucional para filosofar tenha um sucesso imenso que nenhum professor de filosofia do sistema sonhou alguma vez ter. Seu sucesso seria, nesta visão, o próprio fracasso do sistema vigente. (Ver PONTIN, 2018). Seria bom que fosse assim, pois isto configuraria realmente um confronto de ideias. A minha visão é que essa rejeição passa por outro lado, é uma rejeição política (e ontológica afinal das contas). Um aparente confronto entre duas maneiras de fazer filosofia não conseguiria provocar toda essa ira e todo esse tumulto; na verdade, esse confronto está emocionalmente sobrecarregado pelo conflito radical entre direita e esquerda como foi antes descrito; a filosofia vai aqui "de carona", como um conteúdo eventual.
} 
pelo outro, eu prefiro considerar que a aproximação da direita com o autoral e da esquerda com o institucional é puramente contingente e que, portanto, pode mudar no futuro e, na verdade, já pode começar a mudar agora mesmo. Isto abre a possibilidade de assumir uma atitude de esquerda em política e, ao mesmo tempo, defender uma noção autoral da filosofia, o que pareceria inclusive mais coerente com uma política emancipadora de esquerda. (Obviamente, pelo outro lado, já existem, sem dúvida, pensadores da direita favoráveis a um projeto institucional, não forçosamente coincidente com o projeto uspiano).

Mas então, nós poderíamos querer defender uma forma de fazer filosofia como a representada por (1)-(5), sem ter por isso que engajar-nos com a direita política, e querer rejeitar a maneira (A)-(E) de entender a filosofia sem comprar uma briga política com a esquerda (ver seção 3.3). Nesta encruzilhada eu bem gostaria de adotar as críticas olavianas ao projeto institucional da filosofia no Brasil, mas dentro de um arcabouço teórico emancipador e não tradicionalista e religioso, e criticar o establishment filosófico brasileiro não por ser de esquerda, mas por encorajar um tipo de filosofar burocrático e estéril. São dois problemas diferentes. Interessa-me enormemente esta conexão (ou desconexão), porque me considero mais à esquerda que da direita no espectro da política, mas rejeito de plano o projeto institucional da filosofia, e não gostaria que ele estivesse internamente vinculado a um "projeto da esquerda". Aqui estão permanentemente se cruzando esses dois dualismos: direita/esquerda e filosofia autoral/filosofia institucional, o que alimenta uma confusão que pode levar, por exemplo, a rejeitar uma filosofia criativa por ser "de direita" e louvar uma filosofia burocrática e repetitiva por ser "de esquerda".

É precisamente neste ponto em que visualizamos a filosofia no fogo cruzado de direita e esquerda. Aqui é preciso entender que podemos estar muito próximos das ideias políticas de um pensador sem considerá-lo um filósofo autoral; e que podemos aceitar como autoral um pensador com o qual discordamos quase em tudo em política. Um pensador da direita poderia ter todas as propriedades que eu atribuo ao filósofo: pensar em primeira pessoa, ter um aparato próprio de categorias, falar das coisas mesmas em lugar de ficar remoendo em textos sobre textos sobre textos, ser capaz de comover a realidade em lugar de ficar falando dela, ter ousadia e coragem para exprimir ideias irritantes para o estabelecido, expressar-se com clareza meridiana e não em um linguajar técnico incompreensível, mencionar autores para utilizá-los em função do próprio pensamento e não apenas para comentá-los com perfeição técnica.

As críticas de OC ao filosofar acadêmico me parecem, em geral, bem encaminhadas, apesar de corrigíveis e até totalmente rejeitáveis em muitos pontos como em qualquer outra discussão filosófica, mas não tenho nenhuma simpatia pelo seu posicionamento político, especialmente pelo seu descaso pelo tema da emancipação dos excluídos, o não reconhecimento de outras culturas (a sua ideia de que Hernan Cortez foi um libertador dos indígenas), ou pelo seu providencialismo religioso (a ideia de que só Deus pode conduzir o mundo a seu sentido final). Por outro lado, estou bastante próximo da posição política de alguns professores que fazem filosofia burocrática em terceira pessoa, dos "especialistas" em filósofos europeus ou latino-americanos que não têm um rol de categorias próprias e que eu não considero filósofos, mas, na melhor das hipóteses, refinados comentadores de textos. Este é o entrecruzamento trágico que eu vejo entre esses dois dualismos, e que teríamos que fazer esforços para desamarrar, caso estejamos preocupados com os rumos futuros da filosofia no Brasil e com o destino de milhares de jovens que estudam filosofia.

Neste fogo cruzado, tampouco quero assumir uma posição "neutra", mas pensar num novo tipo de militância política, para além do dualismo: "direita versus esquerda", pelo menos nessa formulação extrema que leva para a guerra total. Em meu próprio entendimento do compromisso político, o correto seria lutar pelo plural, pela abertura e pela variedade; o incorreto 
seria o fechamento, a falta de alternativas e o sectarismo de qualquer tendência. A dicotomia relevante seria, em meus termos, pluralismo versus monismo, que podem ser vistos como duas maneiras de elaborar o mal-estar ontológico do ser. A opção monista é caracterizada por colocar o outro no lugar do mal-estar estrutural, de assumir a própria perspectiva como uma verdade que deve ser imposta ao outro lado mesmo contra a sua vontade, vendo a outra parte como mal absoluto a ser destruído na total e absoluta impossibilidade de dialogar com ela. Pelo contrário, chamo de pluralista uma atitude caracterizada pelos seguintes traços: cada perspectiva é sustentável sobre suas próprias bases, trata-se de formas diferentes de organizar a vida que podem opor-se e entrar em conflitos, mas sem nenhuma delas eliminar as outras, e com as quais terá que conviver. Pode-se assumir o pluralismo ou o monismo em qualquer âmbito de ação humana, e, claro, na filosofia em particular.

Neste ponto podemos ver surgindo no horizonte um novo tipo de compromisso político em favor do pluralismo, na medida em que tanto a esquerda quanto a direita parecem ter assumido abertamente, em nossos tempos, alguma modalidade do monismo. $O$ ideal seria que conseguíssemos viver numa sociedade toda ela pluralista, em todos seus aspectos e dimensões, e que esse pluralismo contagiasse de maneira natural à filosofia que fosse feita dentro dela. Formalmente falando, nós estaríamos já vivendo numa sociedade democrática desse tipo, onde há lugar para conservadores, liberais, progressistas, etc., e onde apenas a intolerância, a violência ou o ataque às instituições seria rejeitado. Em muitos países existe revezamento de governos conservadores e governos progressistas. Nas democracias formais há, pois, instituições e um aparato jurídico aparentemente objetivo que só cumpre o que está escrito na lei, e onde o jogo da política é aceito como parte das regras, enquanto ele se mantenha dentro da lei e das instituições. Entretanto, a dura realidade é que as tendências ideológicas, de um lado ou do outro, podem hoje em dia utilizar o aparato democrático para atingir seus adversários sem sair um ápice fora da lei e do respeito pelas instituições. Novamente se faz aqui necessária a diferença entre semântica e pragmática: uma coisa é a formulação literal dos procedimentos democráticos e outra muito diferente o uso que se faz desses procedimentos ${ }^{22}$.

Um caminho mais promissor para um genuíno pluralismo político poderia dar-se, por exemplo, na possibilidade de assumir posturas que adotassem elementos da esquerda e da direita, ou de possibilidades intermediárias; que fôssemos capazes, por exemplo, de adotar da esquerda a ideia de um movimento social endereçado ao futuro, não rigidamente atrelado às tradições do passado, mas adotando da direita a ideia de nenhuma mudança revolucionária ser tentada para realizar esse movimento, mas apenas medidas cautelosas e ponderadas, sem macropolíticas de transformação total. Ou adotar da esquerda a sua preocupação com as imensas desigualdades econômicas e sociais, mas adotar da direita um sóbrio pessimismo antropológico sobre as possibilidades humanas de atingir uma sociedade transparente e sem alienação, e assim por diante. Através dessas composições, talvez muitas pessoas que sustentam posturas moderadas de esquerda ou de direita poderiam se aproximar.

Dentro do plano estrito da filosofia, essa atitude pluralista se daria na possibilidade de debilitar drasticamente o atual projeto institucional exegético, conservando-o apenas como uma opção entre outras, e abrir espaços para um filosofar autoral, quebrando o monopólio que a direita tem tido historicamente (e contingentemente) desse tipo de filosofar, criando a figura de um filósofo com características da esquerda - preocupação pela exclusão e a emancipação

\footnotetext{
22 "[...] a mesma moralidade pode ser utilizada como poderosa arma de dominação; as 'cruzadas pela moralidade,' 'lutas contra a corrupção', e mesmo a aplicação dos procedimentos punitivos contemplados nas leis e na Constituição de um Estado formalmente democrático, mesmo que internamente consistentes, podem ser usados como poderosos mecanismos de discriminação e perseguição, visando motivos particulares" (CABRERA, 2018, p. 137).
} 
- mas capaz de pensar e agir além da mera análise de textos. Nosso compromisso político na filosofia deveria ser com a abertura de espaços para uma filosofia autoral dentro de um projeto intelectual pluralista; tentar sair das limitações da filosofia institucional exegética e do comentário como uma imposição.

É precisamente nessa comunidade plural onde eu gostaria colocar a filosofia, não num inexistente "lugar seguro", mas num âmbito onde ela pudesse se abrir para seus próprios conflitos e compromissos, não herdados de uma luta política imediatista cujas raízes ontológicas asseguram seu caráter interminável. É claro que isto implicaria numa profunda mudança de atitude na intelectualidade, e especificamente nas políticas culturais dos departamentos de filosofia, que deveriam pluralizar suas escolhas sem exclusões partidárias, cultivando uma capacidade de ler e discutir aquilo que tendem a rejeitar no plano político, assim como de não aceitar acriticamente trabalhos filosóficos apenas por virem de posturas políticas favoráveis a seus valores. Podemos perfeitamente criticar um filósofo conservador pelas suas ideias políticas reacionárias, e, ao mesmo tempo, tentar salvar a sua concepção de filosofia. Apreender a pensar sem credenciais. Mas tudo isto implica, é claro, remover a filosofia de uma dicotomia política norteada mais pelas emoções que pela razão, com seus desfechos bélicos inevitáveis.

Resta saber se a escolha pluralista é ontologicamente possível. Se não o for, nenhum manejo político conseguirá instaurá-la. Pois é evidente que todas estas propostas vão em direção oposta às tendências monistas que, pelo contrário, preferem acentuar as diferenças e aumentar os conflitos, e que achariam todas estas propostas de pluralismo como absolutamente ingênuas e irrealizáveis. $O$ autor de uma proposta pluralista seria considerado por ambas as partes como um imbecil, coletivo ou individual. Podemos infelizmente supor que os monismos excludentes têm muitas mais chances ontológicas de se impor na situação humana primordial como foi antes descrita. Atitudes como a mútua rejeição absoluta, que nem sequer precisa de conhecimento ou de argumentos, onde cada parte coloca a outra como mero obstáculo a ser removido e que opta pela guerra total, pareceria oferecer uma maneira muito mais atraente de viver a vida intensamente, de enfrentar o mal-estar do ser através da eliminação de adversários colocados no lugar de culpados a serem destruídos. Pelo contrário, pareceria que o pluralismo ameaça afogar esse poderoso ímpeto da vida mediante uma pacificação insípida.

De qualquer forma, contra o que se poderia pensar, o compromisso político com o pluralismo não tem nada de "confortável" pelo fato de pretender se instaurar além do conflito esquerda e direita, como se ficasse "em cima do muro", pois esse compromisso estará fatalmente sujeito a ser bombardeado por ambos os lados sem poder abrigar-se em nenhum deles. Tradicionalmente, todas as propostas políticas têm atrelado a filosofia (assim como a arte, o cinema, etc.) a determinados programas culturais de tendência definida; elas nunca estiveram abertas para abrigar todo tipo de filosofia.

Na melhor das hipóteses, a triste constatação é que, pelo menos por enquanto, somente poderemos tentar fazer filosofia de uma maneira plural dentro do escopo de uma sociedade monista (da tendência que for), numa estranha forma de parasitismo intelectual, mais ou menos como o excelente cinema argentino surgiu numa situação econômica e política calamitosa e no meio de conflitos acirrados. Poderemos ser tão pluralistas quanto os monismos de esquerda ou de direta - ou das novas oposições que surgirão no futuro - nos permitam ser. Num mundo cada vez mais agressivo e intolerante, qualquer projeto de abertura e diversidade é hoje utopia, ingenuidade, cumplicidade ou imbecilidade. Filosofias autorais que pretendam florescer em ambientes abertos serão arrasadas por dicotomias ao mesmo tempo efêmeras e persistentes. 


\section{Referências}

ARMIJOS, G. De como fazer filosofia sem ser grego, estar morto ou ser gênio. Goiânia: EdUFG, 2004a. ARMIJOS, G. Alheio olhar. Goiânia: EdUFG, 2004b.

ARONSON, R. Camus-Sartre. O polêmico fim de uma amizade no pós-guerra. Rio de Janeiro: Nova Fronteira, 2007.

CABRERA, J. “Por qué no agrado a los rebeldes”. Philósophos. Goiânia, v. 6, 2001. p. 115-128.

CABRERA, J. Diário de um filósofo no Brasil. 2. ed. ljuí: Ed. Unijuí, 2013.

CABRERA, J. "Europeu não significa universal, brasileiro não significa nacional". Nabuco, n. 2, 2015. p. 14-47.

CABRERA, J. "Comment peut-on être un philosophe français au Brésil?". Cahiers critiques de philosophie, Paris VIII, vol. 16, 2016. Disponível em: http://www.editions-hermann.fr/4945cahiers-critiques-de-philosophie-n16.html.

CABRERA, J. "Introdução a uma abordagem negativa da argumentação". Signo, v. 42, 2017. p. 147-168.

CABRERA, J. Mal-estar e moralidade. Brasília: Editora da UnB, 2018.

CABRERA, J. Introduction to a Negative Approach to Argumentation. Towards a new ethic for philosophical debate. Cambridge Scholars Publishing, 2019.

CARVALHO, O. de. Lógica da mistificação, ou: o chicote da Tiazinha. 1999.

CARVALHO, O. de. “Leitura do texto 'A filosofia e a visão comum do mundo', de Oswaldo Porchat Pereira". Seminário de Filosofia. Rio de Janeiro, 06 de junho de 2001.

CARVALHO, O. de. O Imbecil Coletivo I. São Paulo: É Realizações, 2006.

CARVALHO, O. de. O futuro do pensamento brasileiro. São Paulo: É Realizações, 2007.

CARVALHO, O. de. A filosofia e seu inverso, e outros ensaios. Campinas: Vide Editorial, 2012.

CARVALHO, O. de. O dever de insultar. Campinas: Vide Editorial, 2016.

CARVALHO, O. de. O mínimo que você precisa saber para não ser um idiota. 34. ed. Rio de Janeiro; São Paulo: Record, 2018.

CARVALHO, M. et alia. Comment peut-on être philosophe...au Brésil? Disponível em: http://www. ruedescartes.org/numero_revue/2012-4philosopher-au-bresil-aujourd-hui/.

DE SOUZA, J. C. A Filosofia entre nós. Ijuí: Editora Unijui, 2006.

FAUSTO, R. Caminhos da esquerda. Elementos para uma reconstrução. São Paulo: Companhia das Letras, 2017.

FLUSSER, V. Fenomenologia do brasileiro. Rio de Janeiro: Eduerj, 1998.

GOMEZ, R. Crítica da razão tupiniquim. 13. ed. Criar, 2001.

HEIDEGGER, M. Introdução à filosofia. São Paulo: Martins Fontes, 2009.

LOPARIC, Z. Heidegger réu. Um ensaio sobre a periculosidade da filosofia. Campinas: Papirus, 1990.

MARGUTTI, P. História da filosofia no Brasil. 1a Parte. O período colonial (1500 - 1822). São Paulo: Loyola, 2013.

ORTEGA Y GASSET, J. A rebelião das massas. Campinas: Vide Editorial, 2016.

ORTEGA Y GASSET, J. O que é filosofia? Campinas: Vide Editorial, 2016. 
PAIM, A. Liberdade acadêmica e opção totalitária. Um debate memorável. São Paulo: Artenova, 1979.

PÉREZ, D. "Quão obscurantista é o emplasto filosófico de Olavo de Carvalho?". Le Monde Diplomatique, fevereiro 2019.

PIRIE, M. Como vencer todas as argumentações. São Paulo: Loyola, 2008.

PONTIN, F. "As paixões reprimidas de uma massa, o academicismo e a emergência da extrema direita. Entrevista especial com Fabrício Pontin". Revista do Instituto Humanitas - Unisinos, dezembro, 2018.

SARTRE, J.-P. Esboço para uma teoria das emoções. São Paulo: L \& PM Pockets, 2006.

SARTRE, J.-P. O Ser e o Nada. Ensaio de Ontologia Fenomenológica. 12. ed. Petrópolis: Vozes, 2003.

SARTRE, J.-P. Crítica de la Razón Dialéctica. 2. ed. Buenos Aires: Editorial Losada, 1970.

SCHOPENHAUER, A. Parerga y Paralipómena. Madrid: Valdemar, 2009.

\section{Sobre o autor}

\section{Julio Cabrera}

Doutor em Filosofia pela Universidad Nacional de Córdoba. Professor aposentado da UnB, Brasília. Nascido em Córdoba (Argentina), radicado no Brasil há mais de 30 anos, pesquisa nas áreas de filosofias da linguagem e da lógica, linguagem do cinema, éticas negativas e pensamento latino-americano. Autor de em torno 20 livros, sendo os mais importantes: Crítica de la Moral Afirmativa (Barcelona, 1996), Cine: 100 años de Filosofía (Barcelona, 1999), Margens das filosofias da linguagem (2003), Diário de um filósofo no Brasil (2010), Mal-estar e Moralidade (2018) e Discomfort and Moral Impediment (Inglaterra, 2019) e artigos publicados em países latino-americanos (Colômbia, México, Uruguai, Brasil, Argentina, Venezuela) e europeus (Espanha, Portugal, Itália, Alemanha, França). Foi conferencista nas principais universidades brasileiras e no IIF (México), Collège de France, Universidade de Coimbra e Universidade Livre de Berlim entre outras.

Recebido em: 24/06/2020.

Aprovado em: 24/08/2020.
Received: 24/06/2020.

Approved: 24/08/2020. 